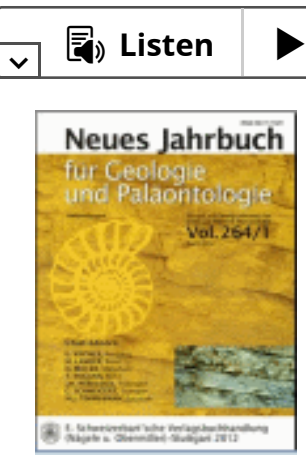

\title{
Fossil assemblages and palaeoenvironments in the Cenomanian vertebrate site of Nazaré (West Central Portugal)
}

Buy Article:

$\$ 39.00$ plus tax

(Refund Policy)

ADD TO CART

BUY NOW

Authors: Callapez, Pedro M.; Barroso-Barcenilla, Fernando; Cambra-Moo, Oscar; Ortega, Francisco; Pérez-García, Adán; Segura, Manuel; Torices, Angélica

Source: Neues Jahrbuch für Geologie und Paläontologie - Abhandlungen, Volume 273, Number 2 , August 2014, pp. 179-195(17)

Publisher: E. Schweizerbart'sche Verlagsbuchhandlung

DOI: https://doi.org/10.1127/0077-7749/2014/0422

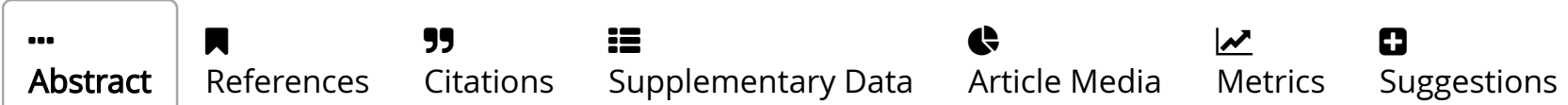

A palaeontological site with early and middle Cenomanian vertebrate remains has been located near Nazaré, a village on the west coast of Central Portugal known for its large promontory with exposures of Upper Cretaceous platform carbonates and "Garumnian" siliciclastic beds. The sampled remains are rather well preserved biomineralized skeletal elements, including bones, teeth and fish scales of disarticulated and fragmented specimens. The vertebrate remains preserve their volume without signs of distortion, and many of the original biological characteristics are still visible. Their taxonomic study allows the identification of several middle Cenomanian osteichthyans, including isolated teeth of Coelodus sp., a few jaw fragments and an almost complete tooth of cf. Enchodus, and a large and articulated teleostean specimen (Teleostei indet.) with well-formed and ossified vertebrae and cycloid scales. The turtle remains are late early Cenomanian in age, and include several indeterminate fragments, besides a costal plate fragment and a complete peripheral plate corresponding to the oldest occurrence of a probable member of the clade PanChelonioidea in the Iberian record. The crocodyliform specimens are represented by three osteoderms of Mesoeucrocodylia indet. and a dorsal vertebra collected from middle Cenomanian beds. This last element is attributed to Eusuchia, a clade poorly known in the European Cenomanian. The late early Cenomanian assemblage with sea turtles and associated benthic faunas have been interpreted as the record of an open inner shelf environment with bivalve biostromes of llymatogyra pseudoafricana and Ceratostreon flabellatum located close to an intertidal flat with mixed carbonate-sand sedimentation. The inner shelf episode was followed by the development of a lagoonal environment during the middle Cenomanian, with oyster communities of Gyrostrea ouremensis and a diverse vertebrate assemblage with several fish and crocodyliform species adapted to more restricted ecological conditions. These new discoveries increase the 
limited number of European locations with Cenomanian vertebrate assemblage records, and provide additional data for several less well known taxa.

Keywords: CARBONATE PLA- TFORM; CENOMANIAN; CROCODYLIFORMES; LAGOONAL ENVIRONMENT; NAZARÉPORTUGAL; OSTEICHTHYES; TESTUDINES; VERTEBRATA

Document Type: Research Article

Publication date: 1 de Agosto de 2014

More about this publication?

\section{We recommend}

New material of large-bodied ornithischian dinosaurs, including an iguanodontian ornithopod, from the Quantou Formation (middle Cretaceous: Aptian-Cenomanian) of Jilin Province, northeastern China

Jun, Chen et al., Neues Jahrbuch für Geologie und Paläontologie - Abhandlungen

Some new Eocene elasmobranch reports from the Outer Western Carpathians (Moravia, Czech Republic)

Přikryl, Tomáš et al., Neues Jahrbuch für Geologie und Paläontologie - Abhandlungen

Notes on plated dinosaurs (Ornithischia: Stegosauria), mostly on dermal armor from Middle and Upper Jurassic of England (also France, Iberia), with a revised diagnosis for Loricatosaurus priscus (Callovian, England)

Galton, Peter M. et al., Neues Jahrbuch für Geologie und Paläontologie - Abhandlungen

Phyllodont tooth plates of Bobasatrania scutata (Gervais, 1852) (Actinoperygii, Bobasatraniiformes) from the Middle Triassic (Longobardian) Grenzbonebed of southern Germany and eastern France, with an overview of Triassic and Palaeozoic phyllodont tooth plates

Böttcher, Ronald et al., Neues Jahrbuch für Geologie und Paläontologie - Abhandlungen

New ornithischian dinosaur material from the Lower Jurassic Lufeng Formation of China Irmis, Randall B. et al., Neues Jahrbuch für Geologie und Paläontologie - Abhandlungen
Giant Sauropod Dinosaur Found In Spain American Association for the Advancement of Science, ScienceDaily

Fossil Fish Jaws Give Information On Our Own Remote Ancestors

Uppsala University, ScienceDaily

Salishicetus meadi, a new aetiocetid from the late Oligocene of Washington State and implications for feeding transitions in early mysticete evolution

Carlos Mauricio Peredo et al., Royal Soc Open Sci

Turtles From an Arkadelphia Formation-Midway Group Lag Deposit (Maastrichtian-Paleocene), Hot Spring County, Arkansas, USA

Becker et. al..; Maisch, Harry M.; Chamberlain, John A. et al., Geosciences

\section{A CONTRIBUTION TO THE STUDY OF TUMORS FROM THE PRIMITIVE NOTOCHORD}

N. D. C. LEWIS et al., JAMA Intern Med

\section{Powered by TREND MD}

I consent to the use of Google Analytics and related cookies across the TrendMD network (widget, website, blog). Learn more 
